\title{
IMPACT OF CPO EXPORT DUTIES ON MALAYSIAN PALM OIL INDUSTRY
}

\author{
${ }^{1}$ Ibragimov Abdulla, ${ }^{2}$ Fatimah Mohamed Arshad, \\ ${ }^{3}$ B.K. Bala, ${ }^{4}$ Kusairi Mohd Noh and ${ }^{5}$ Muhammad Tasrif \\ ${ }^{1,2,3,4}$ Institute of Agricultural and Food Policy Studies, University Putra Malaysia, Selangor, Malaysia \\ ${ }^{5}$ Department of Environmental Science, Institut Teknologi Bandung, Bandung, Indonesia
}

\begin{abstract}
In January 2013, Malaysia reduced the export duty structure to be in line with the Indonesia's duty structure. Both countries export crude and processed palm oil. Since Malaysia and Indonesia are close competitors and they compete in the same market, a change in export duty rate in one country will affect the other. Indonesia, as the world's biggest palm oil producer, has drastically widened the values between the crude palm oil and refined palm oil export taxes since October 2011, to encourage more downstream investments and production of refined palm oil products. Under the revised export duty structure, crude palm oil and crude palm kernel oil are cheaper for downstream activities in Indonesia. The new structure is expected to reduce Malaysia's competitiveness in the world market as its export duty is relatively higher. A high export duty results in high price of crude palm oil which is the raw material for processed palm oil. The research questions are: (i) What are the likely future trends of crude palm oil exports under the new crude palm oil export duties? Will it increase, reduce or stabilize? (ii) What are the likely future trends of processed palm oil exports? Will it increase exponentially, stabilize or reduce? To answer these questions, a system dynamics model was developed for the Malaysian palm oil. Application of the system dynamics model provides a framework to understand the feedback structure and how changes in variables impact the behavior of the palm oil industry. This research suggests that with low crude palm oil export duties crude palm oil domestic price, profitability of plantation owners, immature crop, mature crop, total planted area, production and exports of crude palm oil increase, however exports of processed palm oil decrease.
\end{abstract}

Keywords: System Dynamics, Crude Palm Oil Export Duty, Palm Oil Exports

\section{INTRODUCTION}

Export tariffs are applied for fiscal and market balancing purposes. As for fiscal, it is used to raise fund. Export duty is also used as an instrument to narrow the big difference in the level of domestic In a large country, the introduction of export duties would affect the level of world prices. Hence, the effectiveness of such a trade policy critically depends on the correct determination of the optimal level of export duties. prices as against the world prices for individual goods.

Duty tax on exports of CPO from Malaysia was imposed with the objectives of contributing to government revenue, encouraging value-added or downstream processing of Malaysian palm oil and to enhance the marketability of Malaysian palm oil to the world Amiruddin (2003).

Malaysia and Indonesia are the world's largest producers of palm oil. Both countries export crude and processed palm oil. Export duty taxes are imposed on exports of palm oil products by both countries for the purpose of raising government revenue. Later, in the case of Malaysia, it has been used to encourage the downstream Corresponding Author: Ibragimov Abdulla, Institute of Agricultural and Food Policy Studies, University Putra Malaysia, Selangor, Malaysia 
processing. In Indonesia it is used as a means of monitoring the domestic supply of cooking oil particularly during the high oil prices in the world market.

Since Malaysia and Indonesia are close competitors in that they compete in the same market, a change in export duty rate in one country will affect the other. Indonesia, as the world's biggest palm oil producer, has since October 2011, drastically widened the gap between the crude palm oil and refined palm oil export taxes, to encourage more downstream investments and production of refined palm products. Under the revised export duty structure, crude palm oil and crude palm kernel oil are cheaper for downstream activities in Indonesia. It is a boon to the domestic downstream sector. In the international market, cheaper CPO will encourage demand and hence, export. The new structure is expected to reduce Malaysia's competitiveness in the world market as its export duty is relatively higher. A high export duty results in high price of CPO which is the raw material for PPO. This in turn will lead to higher prices for PPO for exports. Realizing this, Malaysia has decided to reduce the export duty structure to be in line with the Indonesia's tax structure.

Since October 2011, exports of CPO increased from 428,810 to 472,502 $\mathrm{mt}$ in December 2012 (Fig. 1). However, export value of CPO decreased from about RM 1.3 billion in October 2011 to RM 1.1 billion in December 2012. Exports of PPO declined from about 1.4 million $\mathrm{mt}$ in October 2011 to 1.2 million $\mathrm{mt}$ in December 2012 while export value of PPO decreased from RM 4.5 billion to RM 2.9 billion in the same period (Table 1). Total export value of oil palm products declined from RM 7.7 billion in October 2011 to RM 5.5 billion in December 2012. In 2011 , total export value of oil palm products indicated RM 80.4 billion while in 2012 it indicated RM 71.4 billion.

Under the new CPO export duties, the possible behavior of CPO and PPO exports in the future is shown in Fig. 2. Will the exports of CPO increase exponentially because of low duty tax or will it stabilize in the future? Will exports of PPO respond to the change in exports of CPO? Or what growth pattern will it exhibit? These questions require a methodology that can estimate the trajectory behavior of these variables in the future.

A number of studies have been carried out to examine the implications of export duties imposed on palm oil. For instance, Shamsudin et al. (1997) studied the impact of export duty liberalization on processed palm oil production, price and trade using econometric simulation model. The results showed that the abolition of export duty raises the domestic price, production and export and world import of palm oil. However the world price, Malaysian export price and domestic utilization are expected to decline. Thus, full abolition of export tax would provide a growth of the palm oil industry in Malaysia. In order to ensure sustainable growth, productivity and efficiency in production and processing should be enhanced. Basri et al. (2007) studied the impact of lifting the export duty on crude palm oil in Malaysia. In this study, a structural equation is developed for crude palm oil and processed palm oil. The scope of the study covered concepts and dynamic specification of Malaysian palm oil market model including oil palm area, supply, local consumption, imports and exports of both products, stock and price relationships. In this model, Indonesian palm oil market and world palm oil price relationships are included because of the considerable impact on Malaysian palm oil trade. The findings showed that lifting export tax on crude palm oil will decrease its export price and hence an increase in export. An increase in crude palm oil export will decrease amount of crude palm oil available for downstream processing and production will be insufficient to cover the sudden shortage. Net decrease in crude palm oil will cause the local processed palm oil supply to fall and local consumption to decline. However, domestic crude palm oil and processed palm oil price will increase. Crude palm oil has to be imported, because of the insufficient crude palm oil for local downstream activities. Alternatively, producers need to focus on ways to increase their productivity by utilizing technological advancements in the face of limited land availability.

Among the methodologies available, system dynamics approach is highly suitable to examine the circular causality phenomenon between variables under a complex system such as in the palm oil industry (Sterman, 2001). The discussions earlier indicate that the relevant variables such as palm oil land area and production indicate an S-shaped growth which suggests the growing dominance of balancing loop in the later years offsetting the exponential growth in 1970s and 1980 s caused by the reinforcing loops. A similar line of arguments can be used to explain the change in behavior of CPO and PPO exports.

Hence this study attempts to use system dynamics approach to answer the specific questions below:

- What is the impact of CPO export duty on Malaysian palm oil industry, mainly on exports of CPO and PPO

- What will be the effect of new export duty which was introduced in January 2013 on palm oil industry, mainly on exports of CPO and PPO 


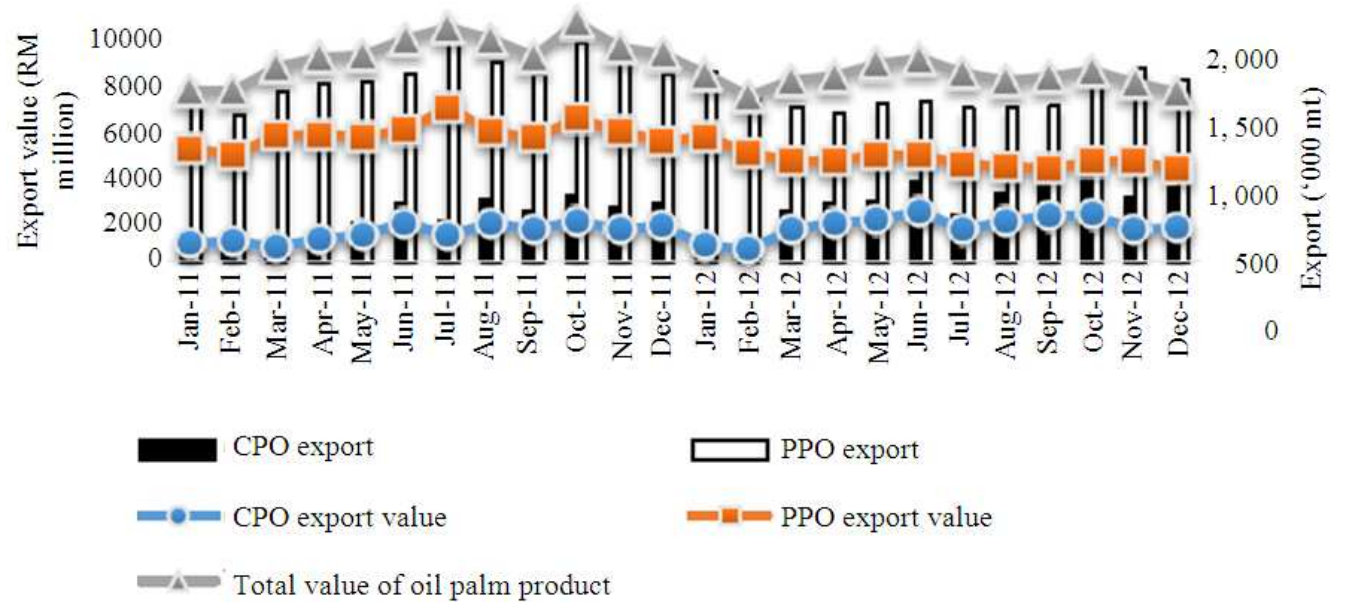

Fig. 1. Monthly export volume ('000 mt) and value (RM million) of oil palm products in Malaysia (2011-2012) Source: MPOB, 2013

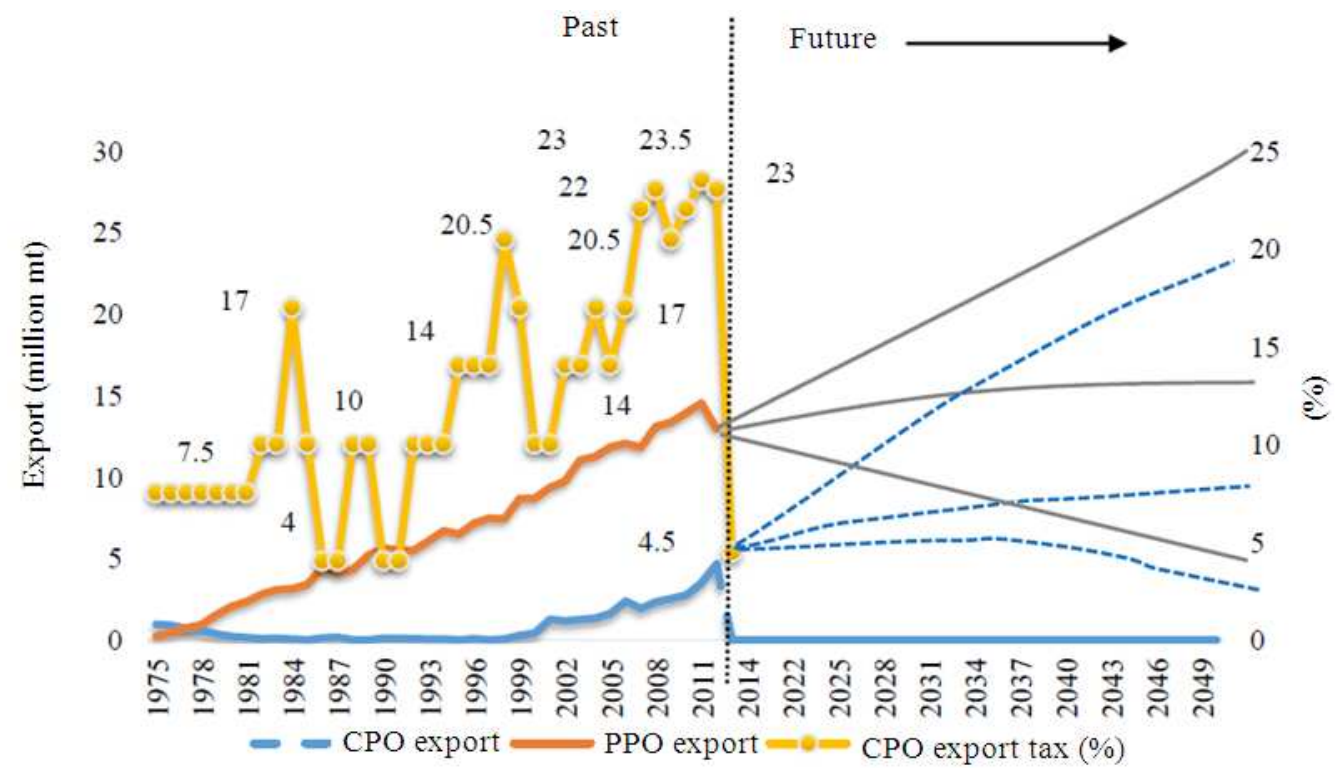

Fig. 2. Scenarios of future behavior of CPO and PPO Export (million mt) Source: MPOB, 2012

Table 1. Error analysis for impact of export duty on malaysian palm oil industry, 1982-2012

\begin{tabular}{|c|c|c|c|c|}
\hline \multirow[b]{2}{*}{ Variable } & \multirow[b]{2}{*}{ RMS percent error $(\%)$} & \multicolumn{3}{|c|}{ Theil inequality statistics } \\
\hline & & Um & Us & Uc \\
\hline New planting & 40.13 & 0.040 & 0.13 & 0.83 \\
\hline Immature crop area & 18.69 & 0.240 & 0.45 & 0.31 \\
\hline Mature crop area & 13.26 & 0.070 & 0.84 & 0.09 \\
\hline Total planted area & 12.75 & 0.120 & 0.81 & 0.07 \\
\hline Production & 17.56 & 0.230 & 0.70 & 0.07 \\
\hline CPO price & 38.17 & 0.001 & 0.62 & 0.38 \\
\hline CPO export & 58.99 & 0.240 & 0.46 & 0.30 \\
\hline PPO export & 16.33 & 0.390 & 0.41 & 0.19 \\
\hline
\end{tabular}


The general objective of the study is to examine the impact of export tariffs on Malaysian palm oil industry. The specific objectives are (i) to examine the impact of changes in the Malaysian export tariffs on palm oil production; (ii) to examine the impact of changes in the Malaysian export tariffs on exports of crude palm oil and processed palm oil; and (iii) to simulate scenarios under different levels of export duties.

\section{MATERIALS AND METHODS}

\subsection{System Dynamics Methodology}

Development of system dynamics modeling began in 1956 by Jay Forrester. To date various methods have been developed and introduced to solve the specific social problems, each has been developed based on the nature of the concern and each has its advantages and drawbacks. The system dynamics method is used to solve complex issues within a system and to identify the behavior of the system during the specific period. Overall dynamic trends such as: Fluctuation, decrease, rise, fall or oscillations are more critical than numerical value of system variables indicated. The core idea used in explaining system structure is responsiveness. Variables in the system are linked by using logic or specific rule in order to change the state of the system. There are two types of variables, endogenous and exogenous. Endogenous variable is a factor in a causal system which occurs in a feedback relationship and its value is determined by the variables in the system. Exogenous variable is a factor which affects the feedback outside of the model. Causal loop diagram helps generalize overall structure and analyzing the system qualitatively. In order to quantify and elaborate a causal loop diagram, further a stock and flow diagram is developed. Stock or level is a variable which accumulates or decreases over time. Exemplary levels are inventories, population and land capacity. A flow rate to or from a stock determines the quantitative value of stock. Relationship among variables can be positive or negative. Feedback loops are differentiated by several ways, the simplest one is by the number of negative links, if negative links are even number or zero, the feedback loop is called reinforcing and it produces exponential growth. If there are odd numbers of negative links feedback loop is called balancing and it can produce oscillatory behavior (Sterman, 2001).

\subsection{Model Conceptualization}

Sterman (2001) on presents a generic structure for commodity markets, adopted from Meadows (1970) who developed initial feedback structure for commodity cycles and applied it to livestock. Generic structure of commodity markets includes most common key parameters such as: Supply chain, price, expected profitability and demand. Meadows and Sterman provide very helpful insights about commodity markets that could be utilized in developing other commodity models. For instance, in his model Sterman showed the representation of the feedback structure for markets as Smith (1776) argued in book "The Wealth of Nations". The concept behind the structure is as follows: Demand for commodity responds to the relative ratio of commodity in contrast with substitutes. Higher relative value increases demand. Supply increases when profits grow and in turn, profits depend on production costs. Higher supply lowers the prices, decreasing profits. Above arguments could also be used in the palm oil commodity system. Meadows (1970) in her book "Dynamics of Commodity Production Cycles" provided the general model of United States hog system. Relationships between inventories and prices and the features of biological, physical and psychological delays are involved in the model. Objective of the research was to derive a general dynamic long-term commodity production cycles and to determine its implications for the projection of commodity stabilization policy.

In the palm oil system dynamics model, there are three main sub-models: Supply, demand and price (Fig. 3).

The balancing loop B1, B2, B3 and B4 represent land availability for oil palm whereas B5, B6 and B7 represent production loop. Considering the maximum land capacity for agriculture, it is possible oil palm area to reach its limit. Available land decreases as the total oil palm area increases. However increase in maximum land capacity will increase available land. Sum of immature crop and total mature crop area gives total oil palm planted area. Available land equals to difference between maximum land capacity and total planted area.

There is only one Reinforcing Loop (R1) in this model and it represents the replanting rate. An increase in planting rate will increase immature crop, young crop, mature crop and old crop area with delay which in turn increases decay rate. There is a positive relationship between decay rate and replanting rate. If replanting rate increases, planting rate will also increase. 


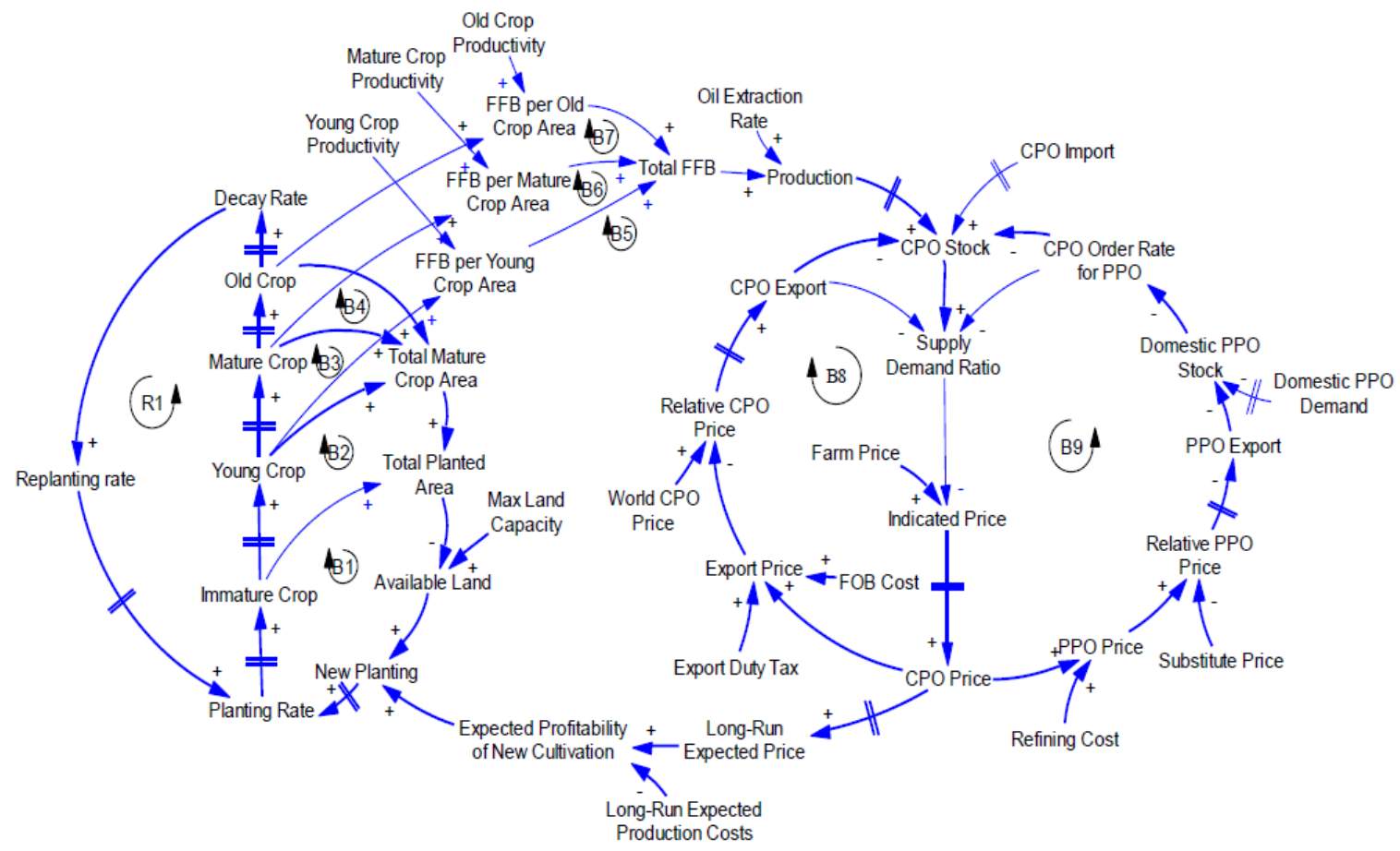

Fig. 3. Causal loop diagram of the Malaysian palm oil industry

The balancing loop B5 represents the profitability of new planting and production cycle. New planting rate includes two factors: New planting and replanting rate. Based on expected price and production cost, profitability of new planting is indicated taking into account the availability of land. Increase in planting rate increases immature crop area which in turn causes to growth in young, mature and old crop area with delay. Consequently, FFB per young crop, mature crop and old crop area and CPO production will increase. Rise in production enhances CPO stock level. If CPO stock increases, supply/demand ratio increases. There is a negative relationship between supply/demand ratio and price. Long-run expected price, expected profitability and new planting will increase in the same direction if CPO price increases.

The balancing loop B8 represents the exports of CPO. Indicated price is formulated due to supply/demand ratio. There is a negative relationship between supply/demand ratio and price. If the supply/demand ratio increases, indicated price and $\mathrm{CPO}$ price will decrease. Export price increases as the FOB cost, export duty and domestic CPO price grow. Surge in CPO export price decreases the relative $\mathrm{CPO}$ price, however raise in the world CPO price increases relative price. In this model, relative CPO price is calculated using world $\mathrm{CPO}$ and Malaysian export price ratio. From that point of view, exports of $\mathrm{CPO}$ increase as the relative $\mathrm{CPO}$ price rises. Consequently, growth of $\mathrm{CPO}$ exports decreases its stock.

The balancing loop B9 represents the exports of PPO. If the CPO price and refining costs increase, $\mathrm{PPO}$ price will also increase. Relative PPO price is ratio of Malaysian PPO price and soybean oil price. If PPO price increases relative PPO price will also increase, however increase in soybean oil price will decreases relative PPO price. High relative PPO price will decrease PPO export level. Surge in exports of PPO will decrease domestic PPO stock. There is a negative relationship between domestic PPO stock and CPO order rate for PPO. If CPO order rate for PPO grows CPO stock will decrease and supply demand ratio also will decrease.

\subsection{Model Formulation}

In this stage causal loop diagram is converted into a stock and flow model, so we will be able to examine the dynamics and run different policy scenarios. To do this, we use modeling software Vensim.

There are four stocks in oil palm area section which are immature, young, mature and old crop area (Fig 4). Immature crop represents the all immature oil palm area in Peninsular Malaysia, Sabah and Sarawak which is done by 
new planting and replanting. In this model, immature crop area increases only by planting rate and decreases by early maturation rate. Immature crop requires 2 years to become productive, whereas late maturation, ageing and decay period takes 10 years, 10 years and 4 years to reach specific level given in the model respectively. Mortality rate of oil palm is not included in the model because of its negligible amount. Number of trees are assumed to be 140 palms per hectare, however in practice 136 to 148 palm trees are planted per hectare due to soil type. Economic cycle of oil palm is approximately 26 years, after that productivity of oil palm declines. In practice replanting rate is decided due to FFB price. In this model replanting rate is set constant $80 \%$ of decay rate. FFB per crop area is calculated multiplying classified oil palm area by their reference productivity. Total fresh fruit bunches are sum of fresh fruit bunches per young crop area, mature crop area and old crop area:

Total FFB $=$ FFB per Young Crop Area + FFB per Mature Crop Area + FFB per Old Crop Area Units: [ton/ha]

There are twelve variables and one stock in Malaysian Domestic CPO stock sub section. CPO production rate of Malaysia is calculated multiplying total FFB by Oil Extraction Rate (OER). Oil extraction rate is capability of machine to extract palm oil and it is given in percentage. Malaysian domestic CPO stock increases by domestic CPO production and CPO import. $\mathrm{CPO}$ production rate is calculated as follows:

$$
\begin{gathered}
\text { CPO Production Rate } \\
=\text { Total FFB } * \text { Oil Extraction Rate } \\
\text { Units: [ton/year] }
\end{gathered}
$$

Outflow CPO order rate for PPO is calculated using function Minimum (MIN) in order not to exceed the CPO order rate for PPO from maximum order rate. From historical data it is observed that entire CPO in the stock can not be ordered for producing Processed Palm Oil (PPO) at once because of the increasing rate of CPO export.

In commodity markets, controlling the level of inventory is one of the central issue for suppliers. On the demand side, delivering goods to destinations on time is main concern. Inventory coverage (the ratio of existing inventory level to consumption) can be an excellent measure to show the effect of supply and demand on price (Sterman, 2001). Malaysian total domestic CPO stock includes CPO production and CPO import. Total demand is sum of CPO export and CPO order rate for PPO which includes PPO export and PPO domestic consumption. Inventory coverage is the ratio Malaysian domestic CPO stock to total demand. Desired inventory coverage is defined as average of supply/demand ratios based on historical data. Relative inventory coverage is a dimensionless variable that compares actual with desired supply demand ratio.

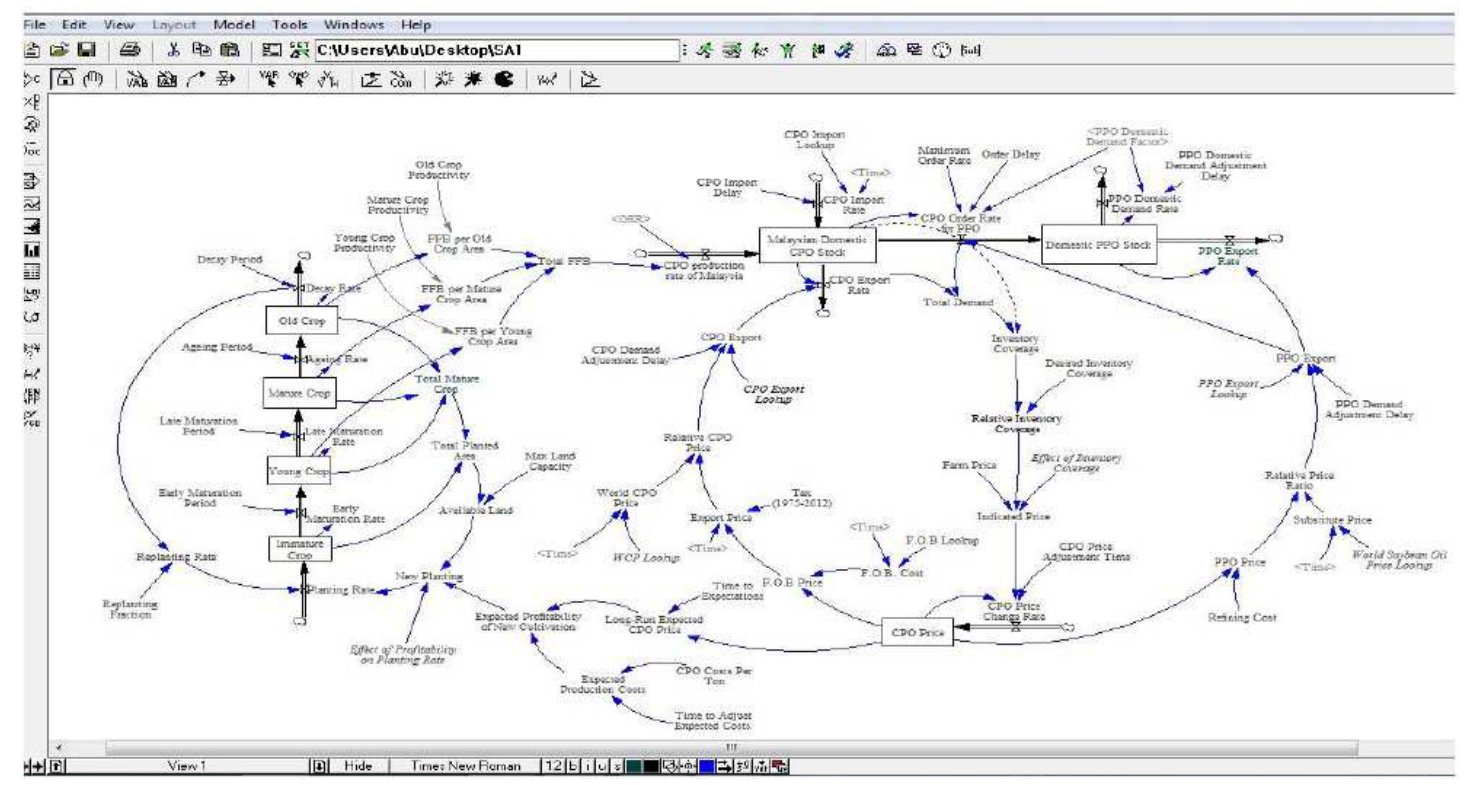

Fig. 4. Vensim ${ }^{\circledR}$ DSS full stock and flow diagram of palm oil 
Indicated price refers to the price, that palm oil should have given the supply and demand. Indicated price is calculated using initial monthly average farm price in 1982 and table function. In the table function, inputs are relative supply demand ratios and outputs are price changes. When the relative inventory coverage is low, price will reach its maximum and when the inventory coverage increases price will decrease.

IF then else function is used to show the impact of export duty:

Export Price $=$ IF THEN ELSE $($ Time $<=2012$, ("Tax (1975-2012)"("F.O.B Price") +1)*"F.O.B Price", "F.O.B Price"*(1+”Different Tax Level)) [Units: Ringgit of Malaysia]

PPO price is sum of Malaysian CPO Price and PPO refining cost. The total refining cost per ton of palm oil consists about $\$ 25$ or RM 89. Once PPO price is determined, it is compared with substitute price in order to indicate relative price ratio. World soybean oil price is taken as a substitute to PPO price. Relative price is the ratio of PPO price to substitute price. It is assumed that, if the value of relative price increases, the amount of PPO export will increase or vice versa. PPO export is determined using table function. In the table function, inputs are values of relative price ratio and outputs are PPO export amount which are given in percentage form.

Long-Run expected price and expected production costs are formulated using SMOOTH function. Expected profitability of new cultivation is calculated using below formula:

Expected Profitability of New Cultivation $=$ (Expected Long-Run CPO Price-Expected Production Costs)/Expected Long-Run CPO Price [Units: Dimensionless]
Expected profitability of new cultivation indicates the difference between the long-run expected CPO price and expected production costs of CPO per ton (Sterman, 2001). Man and Baharum (2011), argued that production cost differs due to capacity of mills.

\section{RESULTS}

Simulation results are compared with the historical data for 8 variables which are new planting, immature crop, mature crop, total planted area, production of CPO, CPO price, CPO and PPO exports for the period of 19822012. Validation of CPO and PPO exports is illustrated in Fig. 5. Statistical test such as the Mean Square Error (MSE), Root Mean Square Percent Error (RMSPE) and the Theil's inequality test are used to validate the simulation results (Sterman, 1984). The RMSPE for six variables: Immature crop area, mature crop area, total planted area, production and PPO export are smaller (12.75-18.69\%) in contrast with CPO price, new planting and CPO export (38.17-58.99\%) showing that the model variables are in the right direction. High RMSPE for CPO export could be explained as the big difference between the last values of the simulated and actual data. This is largely due to the change in the government policy which allowed some companies to export CPO without duty tax in 2001-2012. Consequently, CPO export amount significantly increased in recent years. Taking into account above case, it can be said that CPO export is almost adequately following the underlying trend in actual values. Since, point estimation is not the main target of this test, the appropriateness of simulation results with actual data can be accepted. Table 1 summarizes the errors for selected variables in the system.

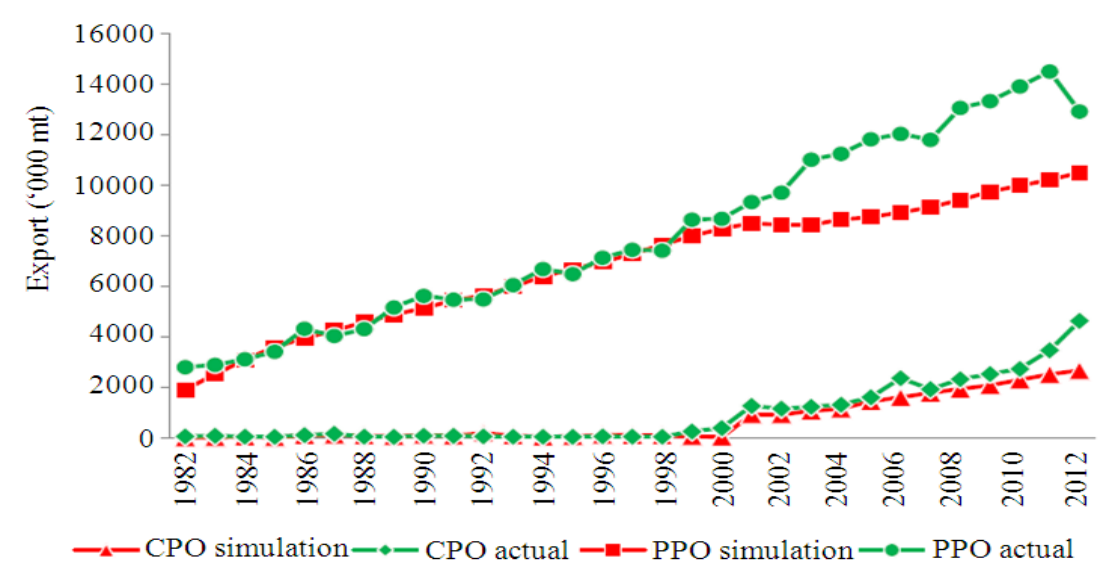

Fig. 5. Validation of CPO and PPO exports 


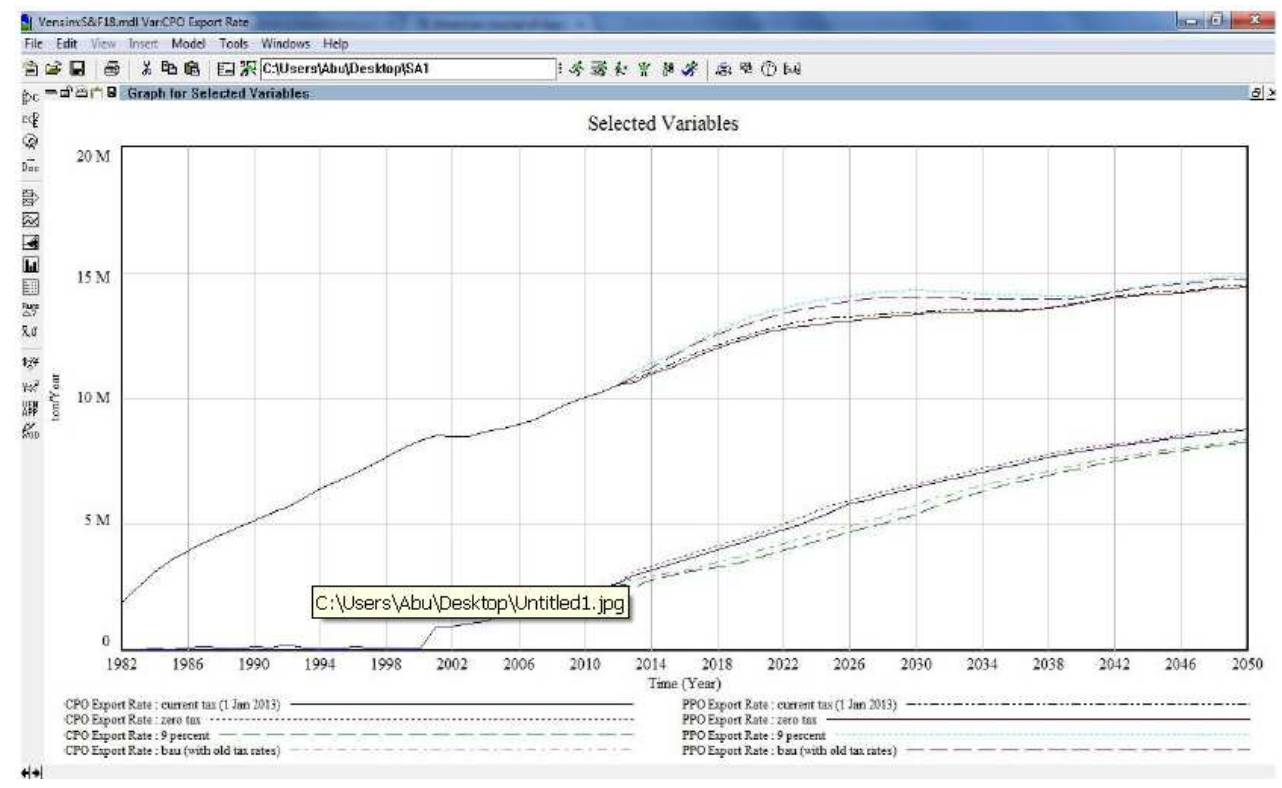

Fig. 6. VENSIM® DSS impact of CPO export duties simulation user interface

As Sterman stated, "All models are wrong". Now we must show that our model is at least sufficient enough to be utilized. The following stage in the modeling process is to run different policy scenarios and to review the behavior. Figure 6 shows the interface used to simulate different scenarios.

\section{DISCUSSION}

Model is run under four different scenarios (Table 2). Under the first scenario, model is simulated without any change to CPO export duty had been implemented until 2012. Scenario 2 examines the implementation of zero tax rate. In scenario 3, model is simulated using new export duty effective since 1 January 2013 whereas scenario 4 is simulated using same CPO export duty rate that Indonesian government impose on exports of CPO nowadays.

From Fig. 6 it can be seen that exports of CPO was low and average CPO export indicated 85,542 $\mathrm{mt}$ in 1982-2000. The reason for low amount of CPO export was government encouraged production of value-added products by imposing exports of CPO to tax. Since 2001 $\mathrm{CPO}$ exports increased exponentially, because of the government permission for selected companies to export $\mathrm{CPO}$ without duty tax. Exports of CPO expected to increase from about 3 million $\mathrm{mt}$ in 2013 to approximately 9 million $\mathrm{mt}$ in 2050 under 4 scenarios.
Table 2. Simulation scenarios

\begin{tabular}{lll}
\hline Scenario & CPO export tax rate & Scenario period \\
\hline 1 (Base run) & Tax rate $=(1982-2012)$ & $1982-2050$ \\
2 & Tax rate $=0 \%$ & $2013-2050$ \\
3 & Tax rate $=4.5 \%$ & $2013-2050$ \\
4 & Tax rate $=9.0 \%$ & $2013-2050$ \\
\hline
\end{tabular}

With the export duty implemented before 2013 (scenario 1), export of CPO is expected to increase from 2.8 million $\mathrm{mt}$ in 2013 to 8.4 million $\mathrm{mt}$ in 2050 indicating increase of $196 \%$, whereas in the same period it is estimated to increase by $176.8,190.1$ and $198.3 \%$ with zero tax (scenario 2), $4.5 \%$ tax (scenario 3 ) and $9 \%$ tax (scenario 4) respectively.

Overall trend of PPO export increased dramatically from only 1.9 million $\mathrm{mt}$ in 1982 to 10.5 million $\mathrm{mt}$ by 8,6 million $\mathrm{mt}$ in 2012 , however it is expected to increase slowly by 2050 under four scenarios. Under scenario 1 , PPO export is expected to grow from 10.8 million $\mathrm{mt}$ in 2013 to 14.7 million $\mathrm{mt}$ in 2050 indicating increase of $35.94 \%$, whereas it is expected to increase by 35.69 , 34.86 and $34.68 \%$ under scenario 2, 3 and 4 .

Simulation results and feedback structure among variables confirm the research findings conducted by Basri (2007).

\section{CONCLUSION}

Findings indicated that the reduction of export duty raises domestic $\mathrm{CPO}$ price, $\mathrm{PPO}$ price, expected 
profitability and production. However, exports of PPO declined. Even though reduction of export tax on CPO would raise the profitability, it may not be fully sufficient to ensure advantages of tax reduction unless further activities are done. For instance, considering the insufficiency of land for oil palm, efficiency and productivity need to be enhanced in upstream and midstream. Low productive trees which are over 26 years have to be replanted.

\subsection{Conflict of Interests}

The authors declare that there is no conflict of interests regarding the publication of this article.

\section{REFERENCES}

Amiruddin, M.N., 2003. Palm oil products exports, prices and export duties: Malaysia and Indonesia compared. Oil Palm Industry Economic J., 2: 19-26.

Basri, A.T., F. Mohd, J. Mohd, N.M. Mohd and Z. Rosli, 2007. Impact assessment of liberalizing trade on malaysian crude palm oil. Oil Palm Industry Economic J., 7: 9-17.
Man, E.L.Y. and A. Baharum, 2011. A qualitative approach of identifying major cost influencing factors in palm oil mills and the relations towards production cost of crude palm oil. Am. J. Applied Sci., $\quad 8$ : 441-446. DOI: 10.3844 /ajessp.2009.267.272

Meadows, D.L., 1970. Dynamics of Commodity Production Cycles. Wright-Allen, Cambridge.

Shamsudin, M.N., M.A. Fatimah and H. Fauziah, 1997. The effect of export duty liberalization on the Malaysian palm oil industry. World Congress.

Smith, A., 1776. The Wealth of Nations. Methuen and Co., Ltd., London.

Sterman, J.D., 1984. Appropriate summary statistics for evaluating the historical fit of system dynamics models. Dynamica, Winter, 10: 51-66.

Sterman, J.D., 2001. Business Dynamics: Systems Thinking and Modeling for a Complex World. 1st Edn., Irwin/McGraw-Hill, New York. 